\title{
Importance Performance Analysis (IPA) in Police Service: A Case Study in Wonogiri Police Precinct
}

\author{
Ruslina Dwi Wahyuni*; Ismi Dwi Astusti Nurhaeni; Rutiana Dwi Wahyunengseh \\ Faculty of Social and Political Science, Universitas Sebelas Maret, Indonesia \\ Email: roselynaa@gmail.com
}

http://dx.doi.org/10.18415/ijmmu.v5i5.435

\begin{abstract}
The purpose of this study was to find out the quality of service and the level of society satisfaction in the service of the Police, especially the Wonogiri Police Precinct in making the Statement of Police Report. The research method was quantitative-descriptive research. The samples of this study were 96 respondents selected using incidental sampling. The data were collected using questionnaires. They were then analysed using the Importance Performance Analysis (IPA) method. The findings in this study showed that the quality of service for making the Statement of Police Report on the Wonogiri Police Precinct in general is categorized as good, but overall it can be concluded that it is not satisfactory and needs improvement. The implication of this research is that there is a case that good service does not always produce quality service in accordance with the expectations of society. The results of this study are expected to be an input to the service unit of the Statement of Police Report at the Wonogiri Police Precinct in improving the quality of its services in line with the expectations of the society.
\end{abstract}

Keywords: Importance Performance Analysis; Satisfaction; Public Services

\section{Introduction}

Public services are an important part in the life of society and nation. Administrative needs that involve certain institutions always require services. Therefore, they should be done properly and optimally to satisfy the needs of the society as the subjects served. Ratminto revealed that good services can only be realized if there are: 1) systems of services that prioritize the interests of the society, especially service users; 2) cultures of services within the organization of service providers; 3 ) humanresource-oriented interests of service users (Ratminto., 2005: 141).

In relation to service quality, according to Moenir (2014: 197), to satisfy the society, the service apparatus must be able to fulfil the 4 basic requirements, namely a) polite behaviour; b) how to convey something related to what should be received by the person concerned; c) the right time to deliver; and d) hospitality.

To improve the quality of public services, local governments should change the paradigms of thinking and acting in the local bureaucracy, from the paradigms of being served, pangreh praja (local 
rulers), governing, and ruling to be the paradigms of serving the society, facilitating and inviting them to participate in the public services, providing excellent services, as well as being responsive, transparent, accountable, and communicative (Malau., 2009: 14).

One of the institutions in charge of serving the society is the police institution. Police is one of the tools of the state and an important component of the judicial system as well as in the prevention of crime. The role of police is needed in order to meet the interests of society and the state. Police is referred to as the Gate Keeper of Criminal Justice. According to article 2 of Law no. 2 year 2002 about the police, it is one of the functions of state government in the areas of: maintenance of security and public order, law enforcement, protection, shelter, and services to the society.

In providing its services, the Police certainly seek to provide the best services, but it is not spared from problems, constraints, and shortcomings, such as those contained in online news and press releases carried out by the Ombudsman that found some deficiencies in the services by police agencies.

Based on the evaluation of public services by the Ombudsman as the authorized state institution to oversee the implementation of public services throughout Indonesia, this institution has received many complaints about the services of various public-service agencies. One of them is the police service as written in some official Ombudsman websites. Based on the registered data in 2016, the number of complaints reached $160,50 \%$ of which were reported by the society directly without accompaniment. By 2017, the Central-Java Ombudsman received 208 reports from the society. 50\% of them were related to the delay, and $30 \%$ of which were related to not-providing services. The complained agency was a service organized by several government agencies, one of which is the police. (Source: Ombudsman of the Republic of Indonesia).

There are so many types of services in the police, one of which is the service of making Statement of Police Report which is set in Skep KAPOLRI No. Pol: SKEP 816 / IX / 2003, which states that the Statement of Police Report is an official certificate issued by the Police of the Republic of Indonesia at the request of a person as he/she needs to fulfill one of the requirements stipulated in relation to professions or other activities. The report contains records of whether or not a person has committed a crime or violation of social norms and is registered as a member of a banned organization. The forbidden organizations are the separatist movement, the Communist Party of Indonesia, and terrorism.

\section{Literature Review}

\section{A. Theory of Service}

Services are a process or an activity that connotes to the intangible, the abstract (Drajad et al., 2004: 44). Services can also be interpreted as a given activity to help, prepare, and take care of either goods or services from one party to another (hardiyansyah., 2011: 11). On the other hand, Manoarfa (2012: 1) said that public services are a service targeted to the satisfaction for anyone who receive it.

According to Parasuraman, Zeithaml, and Berry in the International Journal of Police Science \& Management Volume 14: October 2, 2011, on Public Perceptions of Police-Service Quality: Empirical Evidence from Pakistan: Managing service quality is imperative and service organization must take into consideration the needs and wants of their customers. It means that maintaining the quality of services is very important. Every organization of the service providers should be very understanding of the society's needs to meet all the criteria that the society expects themselves to meet their needs.

Akhtar (2012) stated, "Police services are becoming more complex with the passage of time and the importance of inducting the best human capital in the police has increased." It means that police 
services face complex problems and obstacles so that there needs to be an improvement especially from the human resources from the police itself. In improving the quality of its services, the police must make improvements, innovations, and efforts in terms of services to the society.

\section{B. Service Dimensions}

There are many dimensions of services proposed by experts. Parasuraman, Zeithaml, and Berry (2009: 111), quoted in Basrah Saidani (2012), revealed that there are 5 dimensions to consider in viewing the benchmarks of services; they are:

1. Reliability is the ability to provide the appropriate services as promised appropriately which includes the suitability of performance with customer expectations (timeliness, equal services for all customers, sympathy, and high accuracy).

2. Responsiveness is the ability to help and provide fast and responsive services to customers with clear information.

3. Assurance (guarantee) includes the ability to bear trust and confidence in customers that includes knowledge, politeness of compensation, and the ability of company employees to bring trust to customers to the company.

4. Empathy is emphasizing the treatment to customers as individuals which includes the requirements to care, have understanding and knowledge about customers, understand their needs specifically, and have a comfortable operating time for customers. It is individual attention given by the company to customers such as ease of contacting the company, the ability of employees to communicate with customer's and the company's efforts to understand the desires and needs of its customers.

5. Tangibles is physical evidence, focusing on elements that achieve physical services which include physical facilities, locations, such as buildings and front office spaces, availability of parking lots, cleanliness, neatness and comfort of rooms, tools and equipment (technology, completeness of communication equipment) used, and the appearance of employees.

The police have their own service standards in performing their services. The followings are the standard principles of the issuance procedures of the Statement of Police Report as outlined in the Regulation of the Chief of Police of the Republic of Indonesia No. 18 Year 2014 Article 3:

1. Legality, meaning that the issuance of the Statement of Police Report is in accordance with the provisions of legislation.

2. Transparency, meaning that the issuance of the statement is done clearly and openly.

3. Accountability, meaning that the issuance of the statement must be accountable.

4. Non-discrimination, meaning that the statement is issued to every applicant who has fulfilled the requirements without discriminating one from the other.

5. Necessity, meaning that the statement is issued on the basis of consideration of necessities that are really needed and beneficial to the applicant. 
6. Effectiveness and efficiency, meaning that the statement is issued easily, inexpensively, fast, and comfortably.

From several dimensions of the quality of public services described above, the authors combined the measurement of service quality proposed by Zethaml, Parasuraman, and Berry with the five dimensions of public services-reliability, responsiveness, assurance, empathy, tangible, and accountability (the dimension of the police-service standard that has not been reinforced, according to the authors). This theory has been tested. It also has included the standard dimensions of services applied in the police and is more relevant to this research.

\section{Methodology}

This research was a descriptive research with quantitative approach in which the data were processed using Importance Performance Analysis (IPA). The population in this research was all people who ever got the Statement of Police Report in Wonogiri Police Precinct. The sample was selected using incidental-sampling method, a sampling technique by accident. It means that anyone who accidentally meets the researcher and deems appropriate with the sample characteristics becomes the source of data.

The data were then analysed using Importance Performance Analysis (IPA) method. According to Kotler in Kotler (2000: 49), one of the instruments to assess whether the quality of the service provided by a company is in line with the its performance and customers' expectations/importance. To determine the steps needed to improve them is using Importance Performance Analysis (IPA). From the analysis, we can know the rank of each service attribute of each quality-variable from the performance and expectation (importance) point of views according to the results of customers'/respondents' scoring.

The calculation uses the following formula:

$T k_{i}=\frac{X_{i}}{Y_{i}} \times 100 \%$

(John Martila and John C. James quoted by Supranto., 2006: 241)

Notes: $\mathrm{Tk}_{\mathrm{i}}=$ suitability of respondents, $\mathrm{Xi}=$ score of actual-service performance assessment, and $\mathrm{Yi}=$ score of customer-expectation assessment.

Testing criteria: If $\mathrm{Tk}_{\mathrm{i}}<100 \%$, the service is unsatisfactory; if $\mathrm{Tk}_{\mathrm{i}}=100 \%$, it means satisfactory service; and if $\mathrm{Tk}_{\mathrm{i}}>100 \%$, it means that the service is very satisfactory.

Since the number of populations was tentative, the sampling used the following formula (Lwanga and Lemeshow, 1991):

$\mathrm{n}=\frac{Z^{2} \times P(1-P)}{d^{2}}$

Notes: $\mathrm{n}=$ minimum number of samples required, $\mathrm{Z}=$ confidence level. $\mathrm{Z}$ value at the confidence of $95 \%$ $=1.96, \mathrm{P}=$ estimated population proportion, maximum estimation $=0.5$., and $\mathrm{d}=$ alpha $(0.10)$ or sampling error $=10 \%$

Based on the formula, the number of minimum samples required was 96 . The measurement of the service quality was conducted by comparing the variables of actual services and customer expectations. Each variable consists of 24 factors of services/questionnaire questions, an elaboration of 6 servicequality dimensions. Each question in the questionnaire has been accompanied by the answer choices using a Likert scale. The followings are the examples of questionnaire-questions: 
- For the perceptions of actual-service performance

How do you assess the parking facilities in the service of the Statement of Police Report in Wonogiri Police Precinct? $\left(\mathrm{X}_{\mathrm{i}}\right)$

Table 1 The categories of actual-service performance

\begin{tabular}{lc}
\hline 1 & Not Very Satisfactory \\
2 & Not Satisfactory \\
3 & Quite Satisfactory \\
4 & Satisfactory \\
5 & Very Satisfactory \\
\hline
\end{tabular}

- For customer-expectation perceptions

In your opinion, how important is the availability of parking facilities in the service of the statement of police report in Wonogiri Police Precinct? $\left(Y_{i}\right)$

Table 2 The categories of customer-expectation

\begin{tabular}{lc}
\hline 1 & Not Very Important \\
2 & Not Important \\
3 & Quite Important \\
4 & Important \\
5 & Very Important \\
\hline
\end{tabular}

\section{Result and Discussion}

In this study, the respondents were 96 people who were randomly chosen and had received the Statements of Police Report from Wonogiri Police Precinct. They are distributed as follows:

Table 3 Respondents' gender

\begin{tabular}{lll}
\hline Gender & Frequency & Percentages \\
\hline Men & 77 & $80,2 \%$ \\
Women & 19 & $19,8 \%$ \\
Total & 96 & $100,0 \%$
\end{tabular}

Source: questionnaire data

Based on the above table, most respondents in this study were men i.e. 77 people $(80.2 \%)$ and there were 19 women $(19.8 \%)$.

The research instruments have passed the validity and reliability tests. After all the instruments were valid and reliable for use in the research, the data obtained from 96 respondents and 24 questions in the variables of services and customer expectations were processed using the indicators of 6 dimensions. 5 indicators were from service-quality measurement by Parasuraman, Zeithaml, and Berry (reliability, 
responsiveness, assurance, empathy, tangibility) and the other was from the standard service of the police (accountability).

Table 4 The recapitulation table of responses to the service-quality indicators of the service and customer-expectation variables

\begin{tabular}{|c|c|c|c|c|c|c|c|c|c|c|c|c|c|}
\hline \multirow{2}{*}{$\begin{array}{l}\text { Question } \\
\text { Indicators }\end{array}$} & \multirow{2}{*}{$\begin{array}{l}\text { Gen } \\
\text { der }\end{array}$} & \multicolumn{5}{|c|}{ Services } & \multicolumn{5}{|c|}{ Expectations } & \multirow{2}{*}{$\begin{array}{l}\text { Suitability of } \\
\text { Each Item } \\
\left(\mathrm{Tk}_{\mathrm{i}}\right)\end{array}$} & \multirow[t]{2}{*}{ Conclusions } \\
\hline & & $\begin{array}{l}\mathrm{NV} \\
\mathrm{S} \\
\end{array}$ & NS & QS & S & VS & $\begin{array}{l}\mathrm{N} \\
\mathrm{VI}\end{array}$ & LI & QI & I & VI & & \\
\hline \multirow[t]{2}{*}{ Reliability } & $\mathrm{M}$ & $0 \%$ & $0 \%$ & $3 \%$ & $74 \%$ & $\begin{array}{l}23 \\
\%\end{array}$ & $0 \%$ & $1 \%$ & $2 \%$ & $79 \%$ & $\begin{array}{l}19 \\
\%\end{array}$ & $100,87 \%$ & $\begin{array}{l}\text { Very } \\
\text { Satisfactory }\end{array}$ \\
\hline & W & $0 \%$ & $0 \%$ & $0 \%$ & $88 \%$ & $3 \%$ & $0 \%$ & $0 \%$ & $0 \%$ & $87 \%$ & $\begin{array}{l}11 \\
\%\end{array}$ & $99,68 \%$ & $\begin{array}{l}\text { Not } \\
\text { satisfactory }\end{array}$ \\
\hline \multirow[t]{2}{*}{$\begin{array}{l}\text { Responsiven } \\
\text { ess }\end{array}$} & M & $0 \%$ & $0 \%$ & $3 \%$ & $82 \%$ & $\begin{array}{l}16 \\
\%\end{array}$ & $0 \%$ & $0 \%$ & $3 \%$ & $78 \%$ & $\begin{array}{l}19 \\
\%\end{array}$ & $99,17 \%$ & $\begin{array}{l}\text { Not } \\
\text { satisfactory }\end{array}$ \\
\hline & $\mathrm{W}$ & $0 \%$ & $0 \%$ & $0 \%$ & $97 \%$ & $0 \%$ & $0 \%$ & $0 \%$ & $0 \%$ & $89 \%$ & $5 \%$ & $96,58 \%$ & $\begin{array}{l}\text { Not } \\
\text { satisfactory }\end{array}$ \\
\hline \multirow[t]{2}{*}{ Assurance } & $\mathrm{M}$ & $0 \%$ & $0 \%$ & $4 \%$ & $83 \%$ & $\begin{array}{l}13 \\
\%\end{array}$ & $0 \%$ & $0 \%$ & $3 \%$ & $79 \%$ & $\begin{array}{l}18 \\
\%\end{array}$ & $99,17 \%$ & $\begin{array}{l}\text { Not } \\
\text { satisfactory }\end{array}$ \\
\hline & $\mathrm{W}$ & $0 \%$ & $0 \%$ & $5 \%$ & $89 \%$ & $5 \%$ & $0 \%$ & $0 \%$ & $0 \%$ & $89 \%$ & $\begin{array}{l}11 \\
\%\end{array}$ & $97,88 \%$ & $\begin{array}{l}\text { Not } \\
\text { satisfactory }\end{array}$ \\
\hline \multirow[t]{2}{*}{ Empathy } & $\mathrm{M}$ & $0 \%$ & $0 \%$ & $0 \%$ & $79 \%$ & $\begin{array}{l}21 \\
\%\end{array}$ & $0 \%$ & $0 \%$ & $0 \%$ & $81 \%$ & $\begin{array}{l}19 \\
\%\end{array}$ & $98,68 \%$ & $\begin{array}{l}\text { Not } \\
\text { satisfactory }\end{array}$ \\
\hline & $\mathrm{W}$ & $0 \%$ & $0 \%$ & $0 \%$ & $\begin{array}{l}100 \\
\%\end{array}$ & $0 \%$ & $0 \%$ & $0 \%$ & $0 \%$ & $89 \%$ & $5 \%$ & $97,43 \%$ & $\begin{array}{l}\text { Not } \\
\text { satisfactory }\end{array}$ \\
\hline \multirow[t]{2}{*}{ Tangible } & $\mathrm{M}$ & $0 \%$ & $0 \%$ & $9 \%$ & $78 \%$ & $\begin{array}{l}13 \\
\%\end{array}$ & $0 \%$ & $0 \%$ & $3 \%$ & $79 \%$ & $\begin{array}{l}18 \\
\%\end{array}$ & $98,15 \%$ & $\begin{array}{l}\text { Less } \\
\text { satisfactory }\end{array}$ \\
\hline & W & $0 \%$ & $0 \%$ & $0 \%$ & $89 \%$ & $\begin{array}{l}11 \\
\%\end{array}$ & $0 \%$ & $0 \%$ & $0 \%$ & $\begin{array}{l}100 \\
\%\end{array}$ & $0 \%$ & $100,66 \%$ & $\begin{array}{l}\text { Very } \\
\text { Satisfactory }\end{array}$ \\
\hline \multirow[t]{2}{*}{$\begin{array}{l}\text { Accountabili } \\
\text { ty }\end{array}$} & L. & $0 \%$ & $0 \%$ & $3 \%$ & $81 \%$ & $\begin{array}{l}17 \\
\%\end{array}$ & $0 \%$ & $0 \%$ & $0 \%$ & $84 \%$ & $\begin{array}{l}16 \\
\%\end{array}$ & $98,46 \%$ & $\begin{array}{l}\text { Not } \\
\text { satisfactory }\end{array}$ \\
\hline & W & $0 \%$ & $0 \%$ & $0 \%$ & $95 \%$ & $0 \%$ & $0 \%$ & $0 \%$ & $0 \%$ & $84 \%$ & $\begin{array}{l}11 \\
\%\end{array}$ & $99,04 \%$ & $\begin{array}{l}\text { Not } \\
\text { satisfactory }\end{array}$ \\
\hline
\end{tabular}

Source: the results of data processing

From table above, it can be seen that the society, both men and women, participated in the assessment of public services, especially in the making of the Statement of Police Report in Wonogiri Police Precinct. It was found that the service as a whole was not satisfactory yet even though the service provided was good. It was proven from the percentage near to $100 \%$ despite the overall percentage above $100 \%$. Good responses came from the assessment of women in the tangible dimension and from the assessment of men in reliability dimension indicating the percentage above $100 \%$ (very satisfactory).

After knowing the quality of each service indicator, the quality of the Statement of Police Report in Wonogiri Police Precinct in general was assessed by using the calculation of the total value of suitability (Total $\mathrm{Tk}_{\mathrm{i}}$ ). The total value of $\mathrm{Tk}_{\mathrm{i}}$ was calculated by comparing the total number of actual services provided $\left(\Sigma \mathrm{X}_{\mathrm{i}}\right)$ with the total number of customer expectations $\left(\Sigma \mathrm{Y}_{\mathrm{i}}\right)$. The results of the processed data are as follows:

$\Sigma X_{\mathrm{i}} \quad=9434$

$\Sigma Y_{\mathrm{i}} \quad=9515$ 
Thus, the total suitability value is:

$$
\begin{aligned}
\text { Tk }_{i} \text { Total } & =\frac{\Sigma X_{i}}{\Sigma Y_{i}} \times 100 \% \\
& =\frac{9434}{9515} \times 100 \%=99.1 \%
\end{aligned}
$$

It was obtained that the total value of $\mathrm{Tk}_{\mathrm{i}}$ was less than $100 \%$. It means that the service of making the Statement of Police Report in Wonogiri Police Precinct in general in this study is not in accordance with customer expectations yet or not satisfactory.

\section{Conclusion}

Society as service recipients expect to get the expected good services in accordance with what they want according to their needs. Police officers as service providers are responsible for the quality of services provided to the society, whether it is in accordance with their expectations or not. The findings in this study revealed that the quality of the service unit of the Statements of Police Report in Wonogiri Police Precinct was basically good. However, based on the data that the authors got, it can be concluded that the service provided in general has not been satisfactory. This is based on the calculation of the total value of suitability (Total $\mathrm{Tk}_{\mathrm{i}}$ ) calculated by comparing the actual service provided with the customer expectation with the result of $99.1 \%$. The total percentage of $\mathrm{Tk}_{\mathrm{i}}$ is above $100 \%$ (it can be said satisfactory if it reaches 100\%) which means that the service given by the service unit of the Statement of Police Report in Wonogiri Police Precinct in general has not fulfilled the customer expectation (unsatisfactory). However, the service provided by the service unit of the Statement of Police Report in Wonogiri Police Precinct is generally included in a good category. Therefore, it requires the role of the society as the service recipients to advice towards a better change of all aspects.

\section{Acknowledgements}

This article is based on the research conducted by the authors financed by Lembaga Pengelola Dana Pendidikan (LPDP) of the Republic of Indonesia.

\section{References}

Akhtar, Aisha; Rafiq, Sadaf; Asif, Ali; Saeed, Arshia; Kashif, Muhammad. (2012). Public perceptions of police service quality: empirical evidence from Pakistan, International Journal of Police Science \& Management, 14(2).

KAPOLRI Regulation No.18 2014 about the Issuance Procedure of Statement of Police Report.

Kartono, D.; Jatmiko, Indri; Wibowo, Agung; Amaral, Fransisco; Sudarmo; K, Wiwik Ratna; Purwoko.

Hardjono, Puji. (2004). Administrasi Pelayanan Publik (Public Service Administration). Surakarta: Pustaka Cakra.

Kotler, Philip. (2000). Manajemen Pemasaran (Marketing Management). Millennium Edition. Part 1 \& 2, Prenhalindo, Ltd. Jakarta. 
Lwanga and Lemeshow. (1991). Sampel Size Determination in Health Studies a Practical Manual. Geneva: World Health Organization.

Malau, Habullah. (2009). Menyoal Pelayanan Publik yang Berkualitas di Era Otonomi Daerah (Questioning Quality Public Service in Regional Autonomy Era). Jurnal Ilmiah Politik Kenegaraan 8(1).

VIII No.1 October 2009, Universitas Negeri Padang, p. 14.

Manoarfa, Heryanto. Efektivitas dan Effisiensi Penyelenggaraan Pelayanan Publik: Suatu Tinjauan Kinerja Lembaga Pemerintahan (Effectiveness and Efficiency of Public Service Organization: A Review of Government Institutional Performance). Jurnal Pelangi Ilmu, Vol. 05 No.1 Ed. 2012, Universitas Negeri Gorontalo, p. 1.

Moenir. (2014). Manajemen Pelayanan Umum di Indonesia (Public Service Management in Indonesia). Jakarta: Bumi Aksara.

News.detik.com/.../investigasi-pengurusan-skck-ombudsman-temukan-dugaan.

Ombudsman.go.id/index.php/berita/siaran-pers ombudsman/3091-siaran-pers-ombudsman.

Osborne, David. \& Plastrik, Peter. (1997). Banishing Bureaucracy, Addison-Wesley Publishing Co. Inc. USA.

Parasuraman, A.; Zeithaml, V. A.; Berry, L. L, (1985). A Conceptual Model of Service Quality and Its Implications for Future Research. Journal of Marketing, Vol. 49, Fall.

Ratminto, Atik. (2005). Manajemen Pelayanan (Service Management). Yogyakarta: Pustaka Pelajar.

SKEP KAPOLRI No. Pol: SKEP 816/IX/2003.

Supranto, J., (2006). Pengukuran Tingkat Kepuasan Pelanggan (Customer Satisfaction Measurement), Rineka Cipta. Jakarta, $3^{\text {rd }}$ edition.

UU No. 22002 Article 2 on the Indonesian National Police (State Gazette of the Republic of Indonesia in 2002 Number 2, Supplement to the State Gazette of the Republic of Indonesia Number 4168).

\section{Copyrights}

Copyright for this article is retained by the author(s), with first publication rights granted to the journal.

This is an open-access article distributed under the terms and conditions of the Creative Commons Attribution license (http://creativecommons.org/licenses/by/4.0/). 